\title{
Forestry Practices in Québec and Ontario in Relation to Moose Population Dynamics
}

by

Michel Crête ${ }^{1}$

\section{Abstract}

Abundant forage, particularly twigs of deciduous species, represents the key element of $\mathrm{K}$ carrying capacity for moose. Forest fires previously created such quality habitat, while timber harvest should now play a comparable role. Management units for moose habitat should cover $40-50 \mathrm{~km}^{2}$. Hunting and predation represent the regulating factors of most moose populations in Québec and Ontario, so that habitat is only lightly used. This situation poses difficulties in evaluating the role played by forestry practices on population dynamics; however the logging of a new area, which creates accessibility and removes much cover, greatly exposes moose to hunting until regrowth again provides a visual screen. Moreover, the increasing use of herbicide in forestry, to eliminate deciduous species, represents a potential threat for moose habitat.

\section{Résumé}

Une nourriture abondante, en particulier des ramilles d'essences décidues, constitue l'élément majeur qui détermine la capacité de support de l'habitat de l'orignal. Auparavant, les feux de forêt créaient des habitats de qualité alors que la coupe forestière devrait maintenant jouer le même rôle. L'échelle à laquelle l'aménagement de la forêt doit se faire en ce qui concerne l'orignal atteint $40-50 \mathrm{~km}^{2}$. La chasse sportive et la prédation constitue actuellement les deux facteurs de régulation de la plupart des populations d'orignaux du Québec et de l'Ontario, de sorte que l'habitat est généralement sous-utilisé. Ce phénomène rend difficile l'évaluation du rôle joué par les pratiques sylvicoles sur la dynamique de population; cependant la coupe d'un nouveau secteur, qui crée de l'accessibilité et enlève beaucoup de couvert, rend les orignaux qui l'occupent très vulnérables à la chasse tant que la regenération ne crée pas à nouveau un écran visuel. De plus, l'utilisation de plus en plus grande, en foresterie, de phytocide pour éliminer les essences décidues constitue une menace potentielle pour l'habitat de l'orignal.

\section{Introduction}

The best moose (Alces alces) range in Ontario and Québec is mostly in Rowe's (1972) boreal forest region, but also includes the north part of the Great Lakes-St. Lawrence region (Fig. 1). In such forests, white and black spruce (Picea glauca; $P$. mariana), jack pine (Pinus banksiana) and balsam fir (Abies balsamea) dominate among conifers. They are mixed mainly with white birch (Betula papyrifera) and trembling aspen (Populus tremuloides) (Rowe 1972). Conifer species are of particular interest to the forest industry for pulp and lumber. The influence of logging on moose habitat has been widespread because the industry operates widely in both provinces and is progressing toward the northern limits of the commercial forests.

The moose takes advantage of early seral stages that provide ample forage. Historically, forest fire created such prime habitat; fire rotation averaged 100 years in northern

Ministère du Loisir, de la Chasse et de la Pêche, Québec.
Minnesota before settlement (Heinselman 1973), and varied between 75-200 years in the boreal forest, west of Hudson Bay (Heinselman 1981). On the Kenai peninsula in Alaska fire has remained the major factor for creating early seral communities. The benefit of fire for improving moose density has been well documented (Davis and Franzmann 1979). Forest fires are now controlled in eastern North America because stable and large timber supplies are necessary for profitable logging operations.

Non-consumptive use of moose remains difficult to quantify but the economic importance of hunting is well documented. The demand is high and unsatisfied: 140000 and 96000 licences were sold in 1985 respectively in Québec and Ontario (Roy 1986). Hunter expenses reached \$66 million in 1981 in Québec (Crête 1985) and this created the equivalent of more than 1000 annual jobs (Lacasse and Pelletier 1979). In Ontario, similar statistics for 1986 indicate expenses of $\$ 40$ million. Such a high demand justifies managing most moose populations for maximum sustained yield (MSY) and illustrates the economic importance of moose as an important by-product of the forest. Forestry practices, 


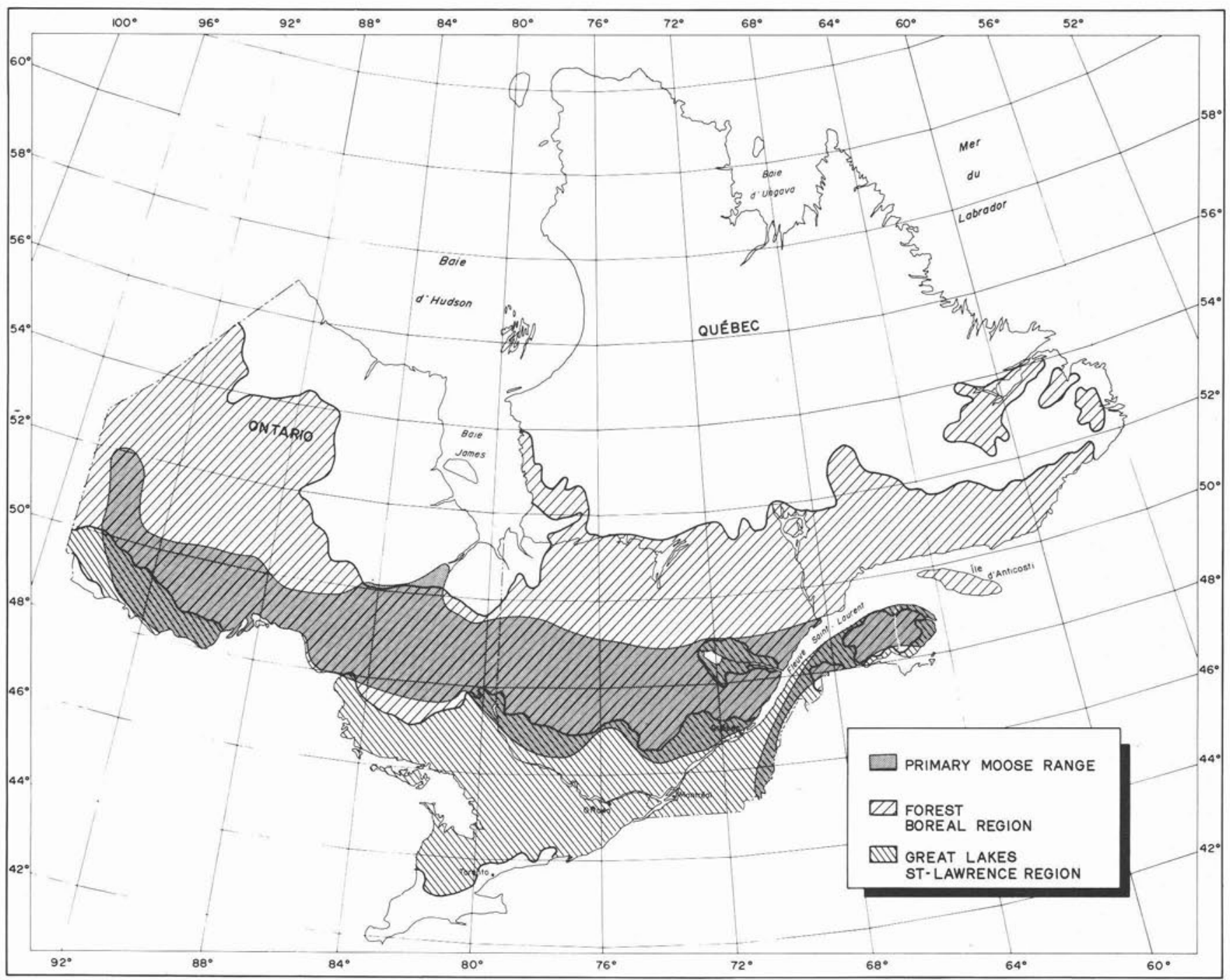

Figure 1. Location of best moose range in Québec and Ontario in relation to Rowe's (1972) forest regions.

which now replace forest fires for creating suitable moose habitat, must then produce good quality habitat, allowing MSY. In this paper I examine how forestry influences moose numbers and harvest.

\section{Examining the Problem at a Moose Scale}

In eastern North America, adult moose use an annual home range covering $20-40 \mathrm{~km}^{2}$, while migratory animals of Alaska may utilize up to $300 \mathrm{~km}^{2}$ (Table 1). Adults of both sexes generally possess comparable home range (Philips et al. 1973; Bangs et al. 1984; Lynch and Morgantini 1984, Crête 1988). However, yearling and 2-year-old moose, particularly males, wander over larger areas (Roussel et al. 1975; Lynch and Morgantini 1984).

The moose shows some behavioural flexibility: on the Kenai Peninsula, Alaska, animals cratered in the snow in search of browse in poor habitat (LeResche and Davis 1973); in Ontario, moose moved out of large clearcuts towards stands with good canopy during mid-winter when snow deepened (Welsh et al. 1980). However a large burn did not affect home range location of Alaskan moose (Gasaway and
Dubois 1985). Forest management then should be such that an animal can find, within $40 \mathrm{~km}^{2}$, all the types of habitat necessary to complete an annual cycle; in Québec, 100-km² blocks have been used as management units (Crête 1977). Late winter habitat, characterized by ample conifer canopy intermingled with forage, has generally been considered critical for moose during periods of deep and/or hardened snow cover (Crête 1977).

\section{Concepts of Carrying Capacity (KCC) and Maximum Sustained Yield (MSY)}

Caughley (1976: 206) proposed the interactive model of growth to depict the relationships existing between a large herbivore and its forage resources. Upon introduction in a virgin habitat, population size of the herbivore will grow with increasing pressure on the vegetation. Consequently, plant biomass will diminish and its composition will change with time; moreover the vegetation community will react to herbivory (Belsky 1986). Plants with indigestible or toxic compounds (ex. Palo 1985), spinescence (Cooper and OwenSmith 1986), etc. will become more common. Eventually a point of equilibrium will be reached between herbivore 
Table 1. Size $\left(\mathrm{km}^{2}\right)$ of home range used by adult moose in 6 areas of North America, as estimated with radio-equipped animals of both sexes.

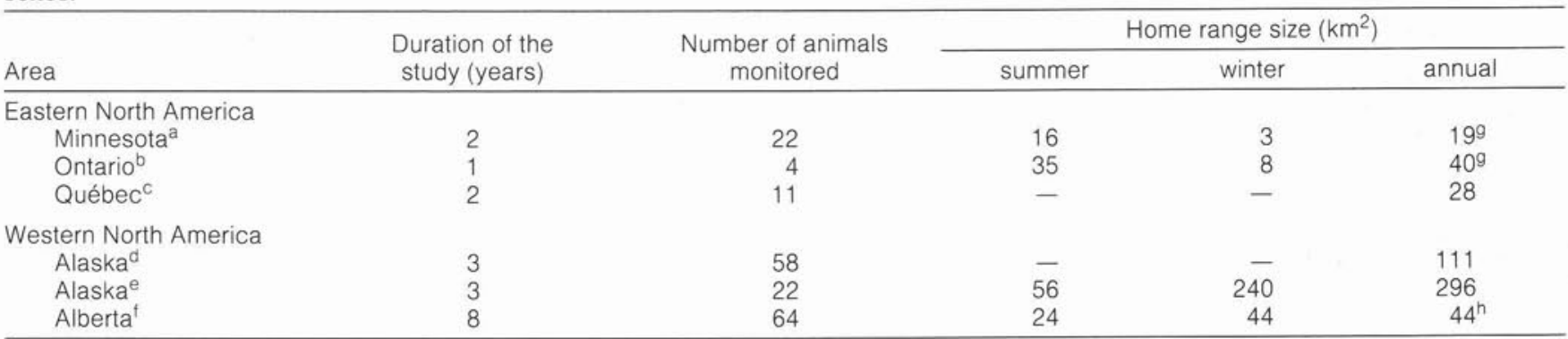

aphillips et al. (1973)

Addison et al. (1980)

Crête (1988)

Bangs et al. (1984)

ETaylor and Ballard (1979)

Lynch and Morgantini (1984)

gestimated

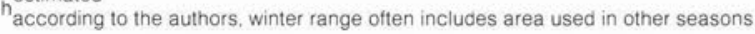

numbers and forage resources or K carrying capacity (KCC: Macnab 1985; Fig. 2A). This model implies that density dependant mechanisms operate to reach an equilibrium. Fecundity and/or survival must decrease along with increasing pressure on forage for KCC to exist.

During the initial phase of colonization birth will exceed death so that the population will increase. This annual surplus represents a possible yield; if hunting is then introduced and the harvest equals the surplus, the population will stabilize. In the case of large herbivores, Caughley (1976) proposed that the relationship between harvestable surplus and density follows a bell-shape curve, slightly skewed toward KCC (Fig. $2 \mathrm{~B})$. This harvest model is applicable to moose management (Crête et al. 1981; Goudreault and Milette 1984)

The interactive model of growth appears plausible for other species of large herbivores when populations are regulated by forage: vicuna (Vicugna vicugna) (Rabinovich et al. 1985), white-tailed deer (Odocoileus virginianus) (McCullough 1979), reindeer (Rangifer tarandus) (Skogland 1986). In the case of moose, Crête (1987) proposed that some

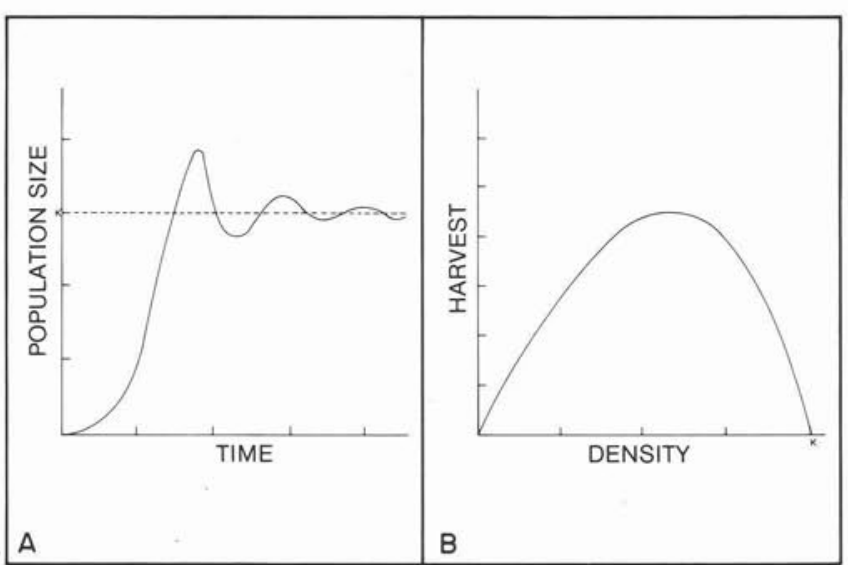

Figure 2. Trajectory of a hypothetical moose population colonizing a virgin area in the absence of predation according to Caughley's (1976: 200) interactive model of growth. (B) Yield-density curve proposed by Caughley (1976) for large herbivore populations regulated by forage. populations preyed upon by only one predator species would be regulated by forage; others, which share their range with gray wolf (Canis lupus) and one species of bear, would be held much below KCC in a "predator pit" (Messier and Crête 1985) even in the absence of hunting. The interactive model of growth would not apply in such cases.

KCC can be approximated by measuring density for unhunted moose populations that reached a relative equilibrium. Table 2 indicates that KCC would exceed 20 moose $/ 10 \mathrm{~km}^{2}$ in some areas of eastern North America where only one large predator species is present; moose density apparently cannot reach $\mathrm{KCC}$ in the absence of hunting when both gray wolf and black bear (Ursus americana) occur (Messier and Crête 1985; Crête 1988).

\section{Regulating Factor at KCC}

Crête (1988), studying a moose population at high density in eastern Québec, observed that the use of deciduous browse in winter was relatively high $(29 \%)$; balsam fir utilization, the only evergreen consumed by moose in the study area was low. When the results of this study were pooled with similar data collected elswehere in Québec, a significant relationship was found between the percentage of deciduous browse used in winter and moose density. Deciduous browse production was then suggested as the key element regulating moose population in Québec. Based on annual production of deciduous twigs only, KCC was estimated to reach 36-60 moose $/ 10 \mathrm{~km}^{2}$ in southwestern Québec. Forage production should be similar in adjacent Ontario.

\section{Forestry Practices and Browse Production}

To maximize KCC, forestry practices should produce maximum deciduous browse. Studies indicated that browse production is favored by logging and peaks 5-20 years after cutting in eastern North America (ex. Vallée et al. 1976; Crête 1977). However no specific study has considered yet how deciduous browse production could be maximized by forest exploitation. Forest industry has favored the growth of conifers and has considered most deciduous shrubs and trees as competitors. Forestry practices must then integrate the needs of the industry and moose managers. For the moment, a minimum annual production of $15 \mathrm{~kg}$ (dry-weight)/ha of 
Table 2. Moose density estimated from aerial census for different unhunted areas of North America (from Crête 1987).

\begin{tabular}{|c|c|c|}
\hline Area & $\begin{array}{c}\text { Density } \\
\left(\mathrm{moose} / 10 \mathrm{~km}^{2}\right)\end{array}$ & $\begin{array}{l}\text { Other large mammals } \\
\text { commonly present }\end{array}$ \\
\hline Gaspésie Park, Qué. & 20 & Black bear \\
\hline Mauricie Park, Qué. & 4 & Black bear, gray wolf \\
\hline $\begin{array}{l}\text { La Vérendrye Game } \\
\text { Réserve, Qué. }\end{array}$ & $4^{a}$ & Black bear, gray wolf \\
\hline $\begin{array}{l}\text { Papineau-Labelle Game } \\
\text { Réserve, Qué. }\end{array}$ & 6 & $\begin{array}{l}\text { Black bear, gray wolf } \\
\text { white-tailed deer }\end{array}$ \\
\hline $\begin{array}{l}\text { Chapleau Game } \\
\text { Preserve, Ont. }\end{array}$ & 4 & Black bear, gray wolf \\
\hline Pukaswa Park, Ont. & 3 & Black bear, gray wolf \\
\hline Isle Royale, MI & 16 & Gray wolf \\
\hline $\begin{array}{l}\text { Voyageur's National } \\
\text { Park, MN }\end{array}$ & 6 & $\begin{array}{l}\text { Gray wolf, black bear } \\
\text { white-tailed deer }\end{array}$ \\
\hline Hecla Island, Man. & 13 & $\begin{array}{l}\text { White-tailed deer, } \\
\text { gray wolf }\end{array}$ \\
\hline $\begin{array}{l}\text { Riding Mountain } \\
\text { Park, Man. }\end{array}$ & 9 & $\begin{array}{l}\text { Elk, white-tailed deer, } \\
\text { gray wolf }\end{array}$ \\
\hline Rochester, Alta & 8 & White-tailed deer \\
\hline $\begin{array}{l}\text { Elk Island Park, } \\
\text { Alta. }\end{array}$ & 15 & $\begin{array}{l}\text { Bison, elk, white- } \\
\text { tailed deer }\end{array}$ \\
\hline Denali Park, AK & 4 & $\begin{array}{l}\text { Dall sheep, caribou, } \\
\text { gray wolf, grizzly } \\
\text { bear }\end{array}$ \\
\hline
\end{tabular}

aEstimated with Caughley's (1976) model and computer simulations.

deciduous twigs should be aimed at on the average over units covering $40 \mathrm{~km}^{2}$; this would ensure that $\mathrm{KCC}$ reaches 20 animals $/ 10 \mathrm{~km}^{2}$ with a target density of 12 moose $/ 10 \mathrm{~km}^{2}$ in areas managed for MSY. Actual densities vary between 0.5 and 4 animals $/ 10 \mathrm{~km}^{2}$ in Québec and Ontario.

The use of herbicides for site preparation before planting conifers or to control deciduous competition in young plantations has increased rapidly during the eighties in Québec (Dussault 1987) and Ontario. Herbicides can potentially lower KCC (Kennedy and Jordan 1985) and will threaten moose habitat if their use becomes widespread.

\section{Cover Requirements}

Moose often utilize large openings in early winter; however, as the season progresses, they tend to move under conifers. DesMeules (1965) concluded that snow depth triggers this shift from open to close habitat, $60 \mathrm{~cm}$ being the critical level above which movements are progressively hindered (Kelsall and Telfer 1974). However even in late winter, the use of the habitat is directly related to the abundance of deciduous browse (Brassard et al. 1974). On the other hand, moose shift to conifers even during winters with little snow (Crête et al. 1986). No study has demonstrated that conifer cover in late winter is necessary to maintain good conditions; abundant forage may suffice. In Québec, $4 \%$ of moose range are left as late winter habitat: such stands, covering at least 3 ha on mesic sites, must possess a minimum conifer basal area of $11 \mathrm{~m}^{2}$ (Crête 1977). These conditions should provide adequate habitat for 10 moose $/ 10 \mathrm{~km}^{2}$.

\section{Forestry Practices and Hunting}

Immediate and drastic consequences of logging on moose population dynamics are to make their habitat more accessible to the hunter and to make the animals more vulnerable because of the destruction of cover. Eason (1985) documented this phenomenon: pre-logging density was estimated at 4.5 moose $/ 10 \mathrm{~km}^{2}$ in his study area, but it dorpped to 1 animals $/ 10 \mathrm{~km}^{2}$ after the first hunting season in the cutover. When regrowth reaches approximately $2 \mathrm{~m}$ in height, moose have access to adequate escape cover, which lowers their vulnerability. The temporary closure to hunting of recent cutover areas has been recommended (Eason 1985). This solution, however, poses some difficulties of enforcement and one must also consider the size of clearcuts: it is useless for cutover covering a few square kilometres, but should be considered when adjacent clearcuts cover 40-50 $\mathrm{km}^{2}$ within approximately 10 years. In such cases, moose can almost vanish from the area. Adequate control of the harvest is an alternative to closing an area to hunting.

\section{Conclusion}

When a herbivore population is regulated by forage, the pressure exerted on vegetation is obvious; for instance browsed species react rapidly when herbivory is reduced by exclosure (ex. moose at Isle Royale: Risenhoover and Maass 1987; white-tailed deer on Anticosti Island: Potvin, F., unpubl. data). Moose densities are generally too low in Quebec and Ontario to really influence the vegetation except on small local areas; there are usually ample vacant habitats. In such circumstances, the impact of forestry practices on population dynamics is difficult to assess. In most areas, hunting and predation appear to regulate moose numbers (Messier and Crête 1985), not timber harvest. However, abundant forage in all seasons appears the major element necessary for healthy moose populations, deciduous species being particularly important. Forestry practices should be such that good habitat is provided everywhere throughout prime moose range. Annual deciduous twig production should equal at least 15 $\mathrm{kg} / \mathrm{ha}$ (dry weight) and some mixed or coniferous stands at least 30-40 years old should be left throughout the territory to ensure adequate late winter habitat. Even if actual populations are much below the density that allows MSY when forage is the regulating factor, managers must prepare for the next century, aiming at producing a land rich in wildlife.

\section{Acknowledgments}

I would like to express my gratitude to T. Timmerman and D. Voigt who provided me some unpublished information. D. Voigt made useful comments on the first draft of this manuscript. Thanks are also owing to J. Berthiaume who drew the figures.

\section{References}

Addison, R.B., J.L. Williamson, B.P. Saunders and D. Fraser. 1980. Radio-tracking of moose in the boreal forest of northwestern Ontario. Can. Field-Nat. 94: 269-276.

Bangs, E.E., T.N. Bailey and M.F. Portner. 1984. Bull moose behavior and movements in relation to harvest on the Kenai National Wildlife Refuge. Alces 20: 187-207.

Belsky, A.J. 1986. Does herbivory benefit plants? A review of the evidence. Am. Nat. 127: 870-892

Brassard, J.M., E. Audy, M. Crête and P. Grenier. 1974. Distribution and winter habitat of moose in Québec. Naturaliste can. 101: 67-80.

Caughley, G. 1976. Wildlife management and the dynamics of ungulate populations. In: Coaker, T.H. (ed.) Applied Biology vol. 1. Academic Press, London, pp. 183-246.

Cooper, A.M. and N. Owen-Smith. 1986. Effects of plant spinescence on large mammalian herbivores. Oecologia (Berlin) 68: 446-455

Crête, M. 1977. Importance de la coupe forestière sur l'habitat hivernal de l'orignal dans le sud-ouest du Québec. Can. J. For Res. 7: 241-257.

Crête, M. 1985. Plan tactique - orignal - Min. Loisir, Chasse Pêche, non publ. 
Crête, M. 1987. The impact of sport hunting on North American moose. Swed. Wildl. Res. (In press).

Crête, M. 1988. Production of forage and its use by a moose population at high density in eastern Québec: estimation of K carrying capacity. J. Wildl. Manage. Submitted.

Crête, M., L.-P. Rivest, H. Jolicoeur, J.-M. Brassard and F. Messier. 1986. Predicting and correcting helicopter counts of moose with observations made from fixed-wing aircraft in southern Québec. J. Appl. Ecol. 23: 751-761.

Crête, M., R.J. Taylor and P.A. Jordan. 1981. Optimization of moose harvest in southwestern Québec. J. Wildl. Manage. 45 598-611.

Davis, J.L., and A.W. Franzmann. 1979. Fire-moose-caribou interrelationships: a review assessment. Proc. N. Am. Moose Conf. Workshop 15: 80-118.

DesMeules, P. 1965. Hyemal food and shelter of moose (Alces alces americana C1.) in Laurentide Park, Québec. M.Sc. thesis, Univ. Guelph. 130 p.

Dussault, C. 1987. Synthèse des techniques sylvicoles dans la forêt publique québécoise. Min. Loisir Chasse Pêche, rapp. int.

Eason, G. 1985. Overharvest and recovery of moose in a recently logged area. Alces 21:55-75

Gasaway, W.L. and S.D. Dubois. 1985. Initial response of moose Alces alces, to wildfire in interior Alaska. Can. Field-Nat. 99(2): $135-140$.

Goudreault, F. and J. Milette. 1984. Influence de la pression de chasse sur la densité des orignaux en hiver: résultats préliminaires. Alces 20:129-160

Heinselman, M.L. 1973. Fire in the virgin forests of the Boundary Waters Canoe Area, Minnesota. Quat. Res. (N.Y.) 3: 329-382.

Heinselman, M.L. 1981. Fire intensity and frequency as factors in the distribution and structure of the northern ecosystems. Tech. Rep. US For. Serv. (Wash. Off.) No. 26. pp. 7-57.

Kelsall, J.P., and E.S. Telfer. 1974. Biogeography of moose with particular reference to western North America. Naturaliste can 101: 117-130

Kennedy, E.R. and P.A. Jordan. 1985. Glyphosate and and 2,4-D: the impact of two herbicides on moose browse in forest plantation. Alces 21: 149-160

Lacasse, M., and J. Pelletier. 1979. Aspects socio-économiques de l'exploitation de l'orignal par la chasse sportive au Québec en 1978. Min. Loisir, Chasse Pêche, non publ.

Leresche, R.E. and J.L. Davis. 1973. Importance of nonbrowse foods to moose on Kenai Peninsula, Alaska. J. Wildl. Manage $37: 279-287$.
Lynch, G.M. and L.E. Morgantini. 1984. Sex and age differential in seasonal home range size of moose in northcentral Alberta, 1971-79. Alces 20:61-78.

MacNab, J. 1985. Carrying capacity and related slippery shibboleths. Wildl. Soc. Bull. 13: 403-410.

McCullough, D.R. 1979. The George reserve deer herd: population ecology of a K-selected species. Univ. Michigan Press, Ann. Arbor, $271 \mathrm{pp}$

Messier, F. and M. Crête. 1985. Moose-wolf dynamics and the natural regulation of moose populations. Oecologia (Berlin) 65 : 503-512.

Palo, R.T. 1985. Chemical defense in birch: inhibition of digestibility in ruminants by phenolic extracts. Oecologia (Berlin) 68: 10-14.

Phillips, R.L., W.E. Berg and D.B. Siniff. 1973. Moose movement patterns and range use in northwestern Minnesota. J. Wildl. Manage. 37: 266-278

Rabinovich, J.E., M.J. Hernandez and J.L. Cajal. 1985. A simulation model for the management of vicuna populations. Ecol. Model. 30: 275-295

Risenhoover, K.L. and S.A. Maass. 1987. The influence of moose on the composition and structure of Isle Royale forests. Can. J. For. Res. 17: 357-364

Roussel, Y.E., E. Audy and F. Potvin. 1975. Preliminary study of seasonal moose movements in Laurentides provincial park, Québec. Can. Field-Nat. 89: 47-52.

Rowe, J.S. 1972. Forest regions of Canada. Can. For. Serv., Publn. 1300 .

Roy, M.-H. 1986. Gros gibier au Québec en 1985 (Exploitation par la chasse et mortalité par des causes diverses). Min. Loisir. Chasse Pêche, SP 1044-06-86.

Skogland, T. 1986. Density dependent food limitation and maximal production in wild reindeer herds. J. Wildl. Manage. 50: 314319

Taylor, K.P. and W.B. Ballard. 1979. Moose movements and habitat use along the Sustina river Devil's Canyon. Proc. N. Am. Moose Conf. Workshop 15: 169-186.

Vallee, J., R. Couture, et R. Joyal. 1976. Etude de la regénération après coupe des essences composant la diète alimentaire de l'orignal. Phytoprotection 57: 155-164.

Welsh, D.A., K.P. Morrison, K. Oswald and E.R. Thomas. 1980. Winter utilization of habitat by moose in relation to forest harvesting. Proc. N. Am. Moose Conf. Workshop 16: 398-428. 